\title{
Implementation of a top five list to identify medical overuse in general practice according to patients' viewpoint in 2019 in France
}

Agnès Hazard $^{1 *}\left(\mathbb{D}\right.$, Marion Debin $^{2}$, Corentin Hervé2 ${ }^{2}$ Caroline Guerrisi ${ }^{2}$, Camille Bonnet ${ }^{2}$ and Mathilde François ${ }^{1,3}$

\begin{abstract}
Background: There is a current trend to reassess the adequacy of care. Establishing top five lists by involving patients is one way to address medical overuse. The objective of this study was to establish a patients' top five list in general practice in France. The secondary objective was to identify selection criteria.

Method: Patients from the web-based cohort GrippeNet.fr were invited to establish their top five list from 15 care procedures previously selected by general practitioners on the basis of medical overuse. The care procedures were presented on a web-interface with guides written with the help of a patient association. A questionnaire was used to explore factors that may have influenced the choices of the participants.

Results: In total, 691 patients established the following top five list: 1/ Prescription of antibiotics for acute bronchitis, nasopharyngitis, otitis media with effusion, or uncomplicated influenza; 2/ Prescription of benzodiazepine and benzodiazepine-like agents for insomnia, generalised anxiety and all indications for older patients; 3 / Prescription of a homeopathic treatment (Influenzinum) for flu prevention; 4/ Prescription of antitussive or expectorant agents for acute cough or acute bronchitis care; 5 / Prescription of statins for the primary prevention of cardio-vascular risk in older patients. More than $70 \%$ of participants gave importance to the recommendations, effectiveness, and tolerance of the care procedures, whereas only half considered the cost.
\end{abstract}

Conclusion: This study is the first to establish a patient's top-five list in general practice. This list provides direction for deciding the main targets in limiting medical overuse.

Keywords: Medical Overuse, General practice, France, Patient

\section{Introduction}

There is currently a trend to limit medical overuse and reassess the adequacy of care to protect the health of patients and make better use of financial resources [1, $2]$. The most consensual definition of medical overuse is "a healthcare service [that] is provided under circumstances in which its potential for harm exceeds the possible benefit" [3]. This phenomenon is multifactorial and

\footnotetext{
*Correspondence: agneshazard@hotmail.com

1 Department of Family Medicine, Faculty of Health Sciences Simone Veil,

University Versailles-Saint-Quentin-en-Yvelines, Villejuif, Paris, France

Full list of author information is available at the end of the article
}

involves both general practitioners (GPs), patients, and healthcare systems [4]. According to doctors, the main cause of medical overuse comes from patient requests [5], with multiple consequences, the main one being the deleterious effect on patient health when they are exposed to overdiagnosis or overtreatment. Overdiagnosis occurs "when a disease is diagnosed in a person when it will never be symptomatic or fatal" [6] and could lead to a subsequent risk of overtreatment, exposing healthy patients to adverse effects of treatments with little or no benefit [7]. Berwick et al. defined overtreatment as "the waste that comes from subjecting patients to care 
that, according to sound science and the patients' own preferences, cannot possibly help them" [8]. This issue is also financial, resulting in the unnecessary overuse of resources. Medical overuse accounted for $30 \%$ of healthcare costs in the United States in 2009 [9] and overtreatment was estimated to represent at least $6 \%$ of healthcare spending in 2011 [8]. This has also been observed in France: the French population was one of the world's largest consumers of drugs, notably the third largest consumer of antibiotics, in Europe in 2018 [10].

Multiple ways to address medical overuse have been developed. The Choosing Wisely campaign, launched by the American Board of Internal Medicine (ABIM) Foundation in 2012, aims to encourage dialogue between doctors and their patients on avoidable acts to reduce their prescription [11]. The principle is based on the creation of lists of five commonly prescribed care procedures (tests, treatments, interventions) that are not supported by evidence and potentially harmful to patients [11]. These lists, called top five lists, have been established in approximately 20 countries for more than 80 specialities [12]. Each list is specific to a specialty and a country.
Seven countries have composed such lists in general practice: the United States [13], Canada [14], Switzerland [15], Australia [16], Italy [17], the United Kingdom [18], and France [19]. These lists are all different. None involved the input of patients, despite the recommendations published by teams of methodologists, who advocate soliciting patients for the determination of top five lists [20]. Health is often in the news in France. The French are very interested in this issue and the results of this study reflect this.

The main objective of this study was to select the first general practice top five list established by patients in France. The secondary objective was to understand the reasons for the patient choices.

\section{Method}

This study is part of a larger project that also included determination of the French top five list in general practice by GPs [19]. The design of the project is presented in Fig. 1 and the protocol has been previously published [21]. The first four steps were common in the establishment of both top five lists (GPs and patients).

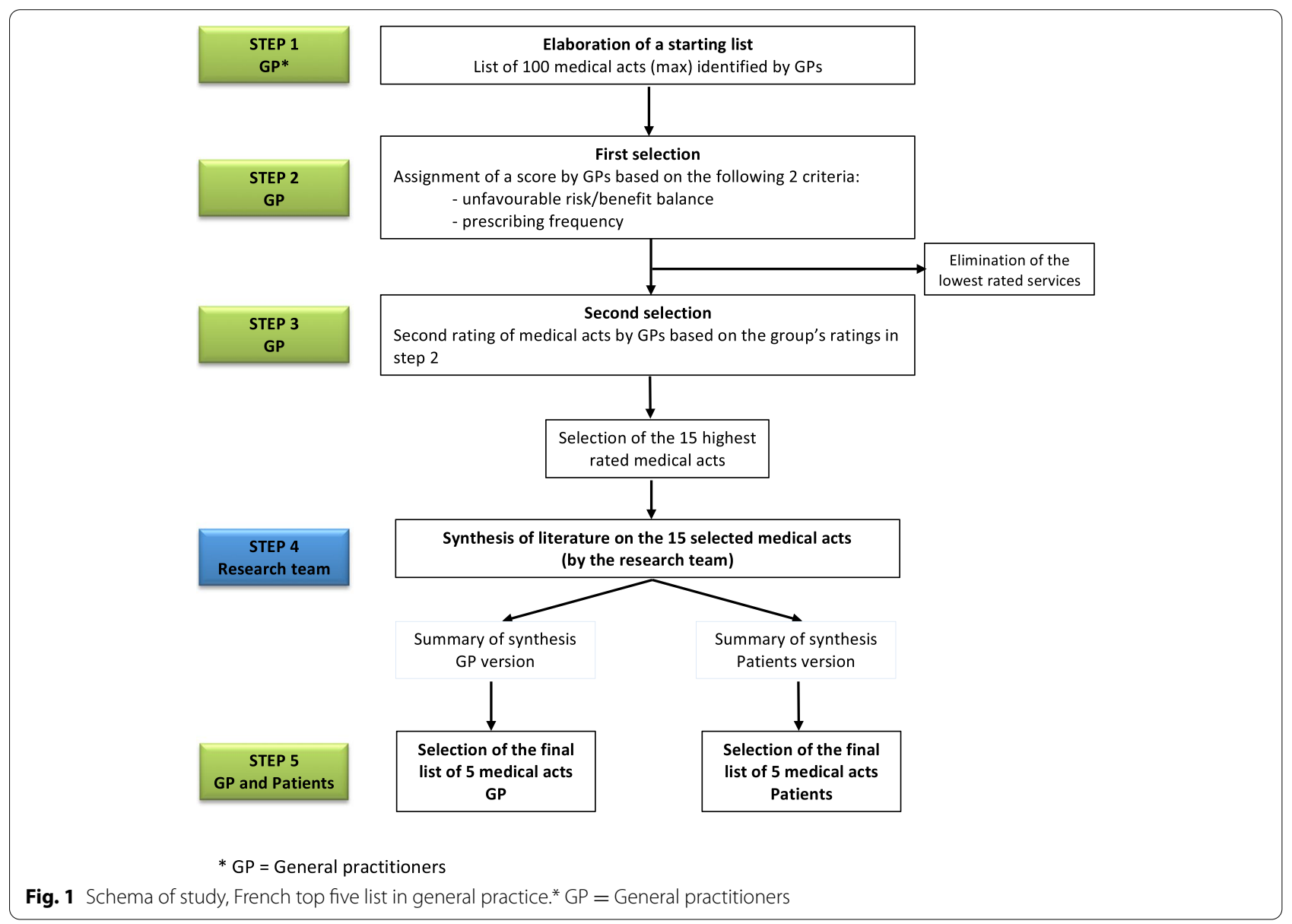


In the first step, 40 GPs selected 100 care procedures considered to be involved in medical overuse. Steps two and three consisted of two Delphi rounds among the GPs, which permitted selection of the 15 care procedures considered to be the most relevant to medical overuse. The fourth step consisted of a literature review for each of the 15 care procedures to write 15 synthetic "guides". Some care procedures were associated with several indications. Literature reviews were conducted for each indication. These guides were first written for GPs and contained didactic information about the efficacy and safety of the care procedure. They also contained the current French recommendations for the care procedure, French or international data on the prevalence and incidence of the condition, and the cost to the French national health service [19]. These guides were concise, as homogenous as possible, and impartial in terms of the presented data. They were proofread by eight academic GPs for clarity and homogeneity. Three of the guides have been published [22-24]. To implement construction of the patients' top five list, two independent researchers adapted the 15 guides to meet requirements related to patients' level of health literacy. The resulting guides were proofread and corrected by expert patients belonging to the "Pemphigus pemphigoïde France" association, which works on written and production of materials for patients with low health literacy language. The finalized guides were reviewed and validated by the study scientific council, which included study investigators, epidemiologists, methodologists and computer scientists. An example of the content of the "patient" guides is available in Additional file 1: Appendix 1.

\section{Study population}

The patient panel was drawn from the web-based GrippeNet.fr cohort, which was launched during the 2011/2012 influenza season to study influenza-like illnesses in the French general population each winter [25]. This cohort occasionally participates in studies on subjects other than influenza [26]. For each participant, data, such as socio-demographic and health characteristics, are available through a background questionnaire that GrippeNet.fr participants complete each year.

A call for participation was sent by email to the GrippeNet.fr participants over 18 years of age who completed a profile survey for the 2018/2019-winter season. Questionnaires from participants who had consulted a GP at least once in the previous 12 months were retained to collect opinions from patients followed in general practice. Study participants could not be identified from the data collected in the study.

\section{Process of the vote}

The 15 care procedures, with their guides, were presented to the participants in a random order on a secured web page developed for the study. Participants were asked to select the five most relevant care procedures in terms of medical overuse and for which the number of prescriptions should be reduced as a priority in general practice. To select a care procedure, patients had to open the corresponding guide (when they clicked on a procedure, the corresponding guide was displayed). Once the five care procedures were chosen, participants had to rank them from one (most unfavourable) to five (least unfavourable).

Once the top five list has been chosen, a short questionnaire was proposed to the participants. Questions focused on the participants' use of the proposed care procedures and various criteria specified in the guides that could have influenced their choices: health authority recommendations, effectiveness, tolerance, and the cost to health insurance. Data were collected using Likertscale questions. The questionnaire is presented in Additional file 1: Appendix 2.

\section{Statistical analyses}

The final patient top five list points to a care procedure depending on its ranking: the first choice received 5 points, the second one 4 points, and so on. The points for each care procedure were then added and the five items with the highest score constituted the top five list.

The distribution of variables related to the criteria that influenced the participants' choices is presented using numbers and proportions.

Three sensitivity analyses were carried out to select the final top five list: the first according to the number of times the care procedures were quoted, regardless of the rank chosen by the participants; the second with sub-group analyses by gender (male $v s$ female), age (less than 60-years vs 60-years-old or more), and educational level (high school or less vs more than high school) of the participants; and the third according to the number of guides consulted by the participants to observe whether reading a guide influenced their choice.

All statistical analyses were performed using $R$ version 1.2.5001.

\section{Results \\ Population characteristics}

Between July 11 and September 1 $1^{\text {st }}$, 2019, 6,449 individuals from the GrippeNet.fr cohort received an email to participate in the current study. Among them, 889 chose a top five list (participation rate: $14 \%$ ). Participants who did not complete the short questionnaire after choosing their top five list $(n=71)$, those who did not complete 
the GrippeNet.fr annual background questionnaire $(n=1)$, and those who did not see a GP in the previous 12 months $(n=126)$ were excluded from the analyses. The final study population included 691 participants. Their characteristics are presented in Table 1. Among the participants, $55 \%$ were over the age of 60 and $65 \%$ were women. Concerning their health, $31 \%$ were undergoing at least one treatment for a chronic condition.

\section{Patients' top five list}

The top five list in general practice, established by patients consisted of:

1. Prescription of antibiotics for acute bronchitis, nasopharyngitis, otitis media with effusion, or uncomplicated influenza.

2. Prescription of benzodiazepines and benzodiazepinelike agents for insomnia, generalised anxiety, and all indications for older patients.

3. Prescription of a homeopathic treatment (Influenzinum) for flu prevention.

4. Prescription of antitussive or expectorant agents for acute cough or acute bronchitis care.

5. Prescription of statins for the primary prevention of cardio-vascular risk for older patients.

The ranking of care procedures did not change depending on the method used (the most cited item or the sum of the points awarded to the procedure (Table 2).

Sub-group results are presented in Tables 3 and 4. In the sub-group analyses of the number of guides consulted, the top five list differed from a single care procedure depending on whether the participants consulted all the guides or less than 10 .

\section{Reasons for choosing items on the top five list}

The distribution of the criteria that influenced the participants' choices is presented in Table 5 . More than $70 \%$ of participants responded that they gave importance to the recommendations of the health authorities, effectiveness, and tolerance to the medical care procedures. Almost half of respondents reported that the cost of the care procedure was not a factor in determining their choice.

Approximately 83\% of the participants were prescribed, personally or for a relative, at least one of the care procedures presented in this study. Among them, 47\% reported having taken the treatment or having undergone the medical exam for each prescription (e.g. Table 5).

\section{Discussion}

This study led to the establishment of the first patients' top five list. Only five American and Canadian published top five lists have involved patients in their development,
Table 1 Socio-demographic and health characteristics of GrippeNet.fr participants $(N=691)$

\begin{tabular}{|c|c|c|}
\hline & $\mathbf{n}$ & $\%$ \\
\hline \multicolumn{3}{|l|}{ Age (in years) $\left(m \cdot d^{a} .=1\right)$} \\
\hline $18-29$ & 11 & 1.6 \\
\hline $30-39$ & 60 & 8.7 \\
\hline $40-49$ & 93 & 13.5 \\
\hline $50-59$ & 144 & 20.9 \\
\hline $60-69$ & 199 & 28.9 \\
\hline 70 and over & 181 & 26.3 \\
\hline \multicolumn{3}{|l|}{ Gender } \\
\hline Female & 450 & 65.1 \\
\hline Male & 241 & 34.9 \\
\hline Level of education (m.d. $=5$ ) & m.d. $=5$ & \\
\hline $\begin{array}{l}\text { No formal qualification, GCSE's levels, CSEs or } \\
\text { equivalent }\end{array}$ & 111 & 16.2 \\
\hline A-levels or equivalent & 116 & 16.9 \\
\hline Bachelor's degree or equivalent & 227 & 33.1 \\
\hline Higher Degree or equivalent & 232 & 33.8 \\
\hline \multicolumn{3}{|l|}{ Main activity } \\
\hline Working & 311 & 45.0 \\
\hline $\begin{array}{l}\text { Stay at home, looking for work or on sick or parental } \\
\text { leave }\end{array}$ & 33 & 4.8 \\
\hline Retired & 332 & 48.0 \\
\hline Student, or other situation & 15 & 2.2 \\
\hline \multicolumn{3}{|l|}{ Treatment for a chronic disease } \\
\hline No & 475 & 68.7 \\
\hline Yes & 216 & 31.3 \\
\hline Asthma & 52 & 24.1 \\
\hline Diabetes & 39 & 18.1 \\
\hline Pulmonary diseases & 31 & 14.4 \\
\hline Heart diseases & 102 & 47.2 \\
\hline Kidney diseases & 5 & 2.3 \\
\hline Immunodeficiency & 38 & 17.6 \\
\hline \multicolumn{3}{|l|}{ Tobacco use } \\
\hline No & 628 & 90.9 \\
\hline Yes, occasionally or $<10$ cigarettes/day & 38 & 5.5 \\
\hline Yes, $\geq 10$ cigarettes/day & 25 & 3.6 \\
\hline \multicolumn{3}{|l|}{ 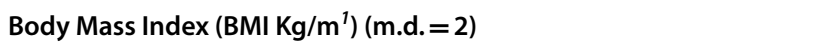 } \\
\hline Underweight & 19 & 2.7 \\
\hline Normal weight & 357 & 51.7 \\
\hline Overweight & 215 & 31.1 \\
\hline Obese & 98 & 14.2 \\
\hline
\end{tabular}

a m.d. missing data

despite the recommendations for developing these types of lists among lay individuals [20], but none in general practice. However, patient participation was limited to comments on the final list already established by American or Canadian rheumatologists, neurologists, and gastroenterologists. They did not participate in the final vote [27-30]. For American neonatal medicine, family 
Table 2 Details and ranking of the 15 care procedures used to define the patients' top five list

\begin{tabular}{|c|c|c|c|c|c|}
\hline \multirow[t]{3}{*}{ Care procedures } & \multirow[t]{3}{*}{ Indication } & \multicolumn{4}{|c|}{ Patients' top five list" } \\
\hline & & \multicolumn{2}{|c|}{$\begin{array}{l}\text { Sum of } \\
\text { points }\end{array}$} & \multicolumn{2}{|c|}{$\begin{array}{l}\text { Number of } \\
\text { citations }\end{array}$} \\
\hline & & Rank & Result & Rank & Result \\
\hline Prescription of antibiotics & $\begin{array}{l}\text { Acute bronchitis, nasopharyngitis, otitis media with effusion, } \\
\text { uncomplicated influenza }\end{array}$ & 1 & 1,539 & 1 & 431 \\
\hline $\begin{array}{l}\text { Prescription of benzodiazepine and benzodiazepine- } \\
\text { like agents }\end{array}$ & $\begin{array}{l}\text { Insomnia, generalised anxiety and in older patients for all } \\
\text { indications }\end{array}$ & 2 & 1,242 & 2 & 389 \\
\hline $\begin{array}{l}\text { Prescription of an homeopathic treatment (Influen- } \\
\text { zinum) }\end{array}$ & Fluprevention & 3 & 1,230 & 3 & 351 \\
\hline Prescription of antitussive or expectorants agents & Acute cough or acute bronchitis care & 4 & 1,000 & 4 & 313 \\
\hline Prescription of statins & Primary prevention of cardio-vascular risk in older patients & 5 & 960 & 5 & 301 \\
\hline Prescription of Tramadol or tramadol with paracetamol & Pain care in older patients & 6 & 764 & 6 & 266 \\
\hline Prescription of lumbar scanner & Low back pain evolving for less than 6 weeks & 7 & 684 & 7 & 259 \\
\hline $\begin{array}{l}\text { Prescription of a non-steroidal anti-inflammatory agent } \\
\text { (NSAID) }\end{array}$ & Symptomatic treatment of acute sinusitis and pharyngitis & 8 & 670 & 8 & 254 \\
\hline Long term prescription of proton pump inhibitors & Without reviewing the indication & 9 & 657 & 9 & 246 \\
\hline PSA Testing & $\begin{array}{l}\text { Systematic screening of prostate cancer in men older than } \\
50 \text { with no information given to the patient regarding the } \\
\text { benefits and risks }\end{array}$ & 10 & 411 & 10 & 153 \\
\hline Mammography & $\begin{array}{l}\text { Systematic screening for breast cancer in women with no } \\
\text { information given to the patient regarding the benefits and } \\
\text { risks }\end{array}$ & 11 & 337 & 11 & 119 \\
\hline Prescription of cholinesterase inhibitors and memantin & Mild cognitive impairment and Alzheimer disease & 12 & 289 & 12 & 113 \\
\hline Prescription of vasodilatator agents & Peripheral Arterial Disease & 13 & 237 & 13 & 100 \\
\hline Prescription of DPP4 inhibitors & Type 2 diabetes & 14 & 195 & 14 & 84 \\
\hline Prescription of allopurinol & $\begin{array}{l}\text { Asymptomatic hyperuricemia in prevention of gout attack, } \\
\text { renal hypertension, cardio-vascular disease }\end{array}$ & 15 & 180 & 15 & 76 \\
\hline
\end{tabular}

representatives participated in the creation of the first list to identify medical overuse care procedures [31].

Consultation of the literature guides did not appear to be the only determinant in the selection of the top five list items. This may reflect pre-study opinions that cannot be changed by reading scientific material. More than $70 \%$ of the study patients had been exposed to at least one of the proposed care procedures. This is consistent with a French poll that reported that $77 \%$ of French individuals have a first opinion on their experience and background [32]. However, it is difficult to estimate the share of the a priori vision that the patients may have had for each care procedure. Finally, we did not seek to recruit patients specifically affected by an indication for which the procedure of care was in question. The purpose of this study was to get away from personal experience by reading the guidelines that provide scientific evidence.

Various information campaigns and controversies recently raised in France may have influenced the top five list as well. First, since 2002, the French population has been exposed to various health insurance campaigns aiming to reduce antibiotic consumption. After a $26.5 \%$ decrease in antibiotic prescriptions in France between
2002 and 2007 [33], an increase was observed in 2009. This led to a new series of awareness-raising campaigns on antibiotic resistance, which have stabilised antibiotic consumption, although France still used 35\% more antibiotics than the European average in 2019 [34]. Concerning benzodiazepines, a French study published in 2014 was widely covered by the media [35]. It showed a positive association between the use of benzodiazepines and the development of dementia. Although these data were called into question in another study in 2015 [36], distrust of benzodiazepines and fear of developing Alzheimer's disease may have remained in the collective memory. Nevertheless, France remains the second largest consumer of benzodiazepines in Europe [37]. Concerning homeopathy, the Haute Autorité de Santé (HAS) decided in June 2019 to remove homeopathic products from the list of medicines reimbursed by the national health insurance, leading to a public debate widely covered by the media [38]. This has also been the case for the use of statins for primary prevention. The "shock" report on the use of statins broadcast on television in December 2017 relaunched a debate already initiated in 2013 by a French doctor with his polemical book "The 
Table 3 Patients' top five list among 15 care procedures, with sub-groups analyses by gender, age, and level of education

\begin{tabular}{|c|c|c|c|c|c|c|c|}
\hline & \multirow{2}{*}{$\begin{array}{l}\text { TOTAL } \\
(n=691)\end{array}$} & \multicolumn{2}{|l|}{ Gender } & \multicolumn{2}{|c|}{ Age, in years } & \multicolumn{2}{|c|}{ Level of education } \\
\hline & & $\begin{array}{l}\text { Male } \\
(n=241)\end{array}$ & $\begin{array}{l}\text { Female } \\
(n=450)\end{array}$ & $\begin{array}{l}\text { Under } 60 \\
(n=308)\end{array}$ & $\begin{array}{l}60 \text { and over } \\
(n=380)\end{array}$ & $\begin{array}{l}\text { High school or } \\
\text { less }(n=227)\end{array}$ & $\begin{array}{l}\text { College } \\
\text { or more } \\
(n=459)\end{array}$ \\
\hline Antibiotics & 1 & 1 & 1 & 1 & 1 & 1 & 1 \\
\hline Benzodiazepines & 2 & 3 & 2 & 2 & 3 & 3 & 2 \\
\hline Homeopathic & 3 & 2 & 3 & 3 & 2 & 2 & 3 \\
\hline Antitussive or expectorant & 4 & 5 & 4 & 4 & 5 & 4 & 4 \\
\hline Statins & 5 & 4 & 5 & 5 & 4 & 5 & 5 \\
\hline Tramadol & 6 & 9 & 6 & 9 & 5 & 6 & 6 \\
\hline NSAID ${ }^{a}$ & 7 & 8 & 9 & 6 & 8 & 8 & 9 \\
\hline Lumbar scanner & 8 & 7 & 7 & 7 & 6 & 7 & 8 \\
\hline Proton pump inhibitors & 9 & 10 & 8 & 8 & 7 & 9 & 7 \\
\hline$P S A^{b}$ & 10 & 6 & 12 & 10 & 9 & 10 & 10 \\
\hline Mammography & 11 & $11-12$ ex aequo & 10 & 11 & 10 & 11 & 11 \\
\hline Cholinesterase inhibitors & 12 & $11-12$ ex aequo & 11 & 12 & 11 & 12 & 12 \\
\hline Vasodilatator agents & 13 & 13 & 13 & 13 & 12 & 13 & 13 \\
\hline DPP4 inhibitors ${ }^{c}$ & 14 & 14 & 15 & 14 & 14 & 15 & 14 \\
\hline Allopurinol & 15 & 15 & 14 & 15 & 13 & 14 & 15 \\
\hline
\end{tabular}

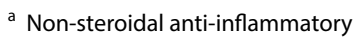

b Prostate specific antigen

c Dipeptidyl peptidase 4 inhibitors

truth about cholesterol", in which he refuted the benefit of statins as a means of primary prevention [39]. It led to a $40 \%$ increase in the proportion of patients stopping statin use within nine months of the book's publication [40]. This "shock" report disturbed the scientific community of cardiologists, who accused the media of establishing irrational and anxiety-provoking conspiracy theories [41]. In 2006, the delisting of mucolytics and expectorants from the list of medicines reimbursed by the national health insurance led to a $50 \%$ reduction in the prescription of

Table 4 Patients' top five list" among 15 care procedures with sub-groups analyses according to the number of consulted guides

\begin{tabular}{|c|c|c|c|c|}
\hline Care procedures & $\begin{array}{l}\text { TOTAL } \\
(n=691)\end{array}$ & $\begin{array}{l}\text { Among the participants } \\
\text { who opened all the guides } \\
(n=106)\end{array}$ & $\begin{array}{l}\text { Among the participants } \\
\text { who opened only } 5 \text { guides } \\
(n=271)\end{array}$ & $\begin{array}{l}\text { Among participants who } \\
\text { opened at least } 10 \text { guides } \\
(n=183)\end{array}$ \\
\hline Antibiotics & 1 & 1 & 1 & 1 \\
\hline Benzodiazepine & 2 & 4 & 3 & 3 \\
\hline Homeopathic & 3 & 2 & 2 & 2 \\
\hline Antitussive or expectorant & 4 & 8 & 4 & 5 \\
\hline Statins & 5 & 3 & 5 & 4 \\
\hline Tramadol & 6 & 7 & 6 & 7 \\
\hline Lumbar scanner & 7 & 5 & 8 & 6 \\
\hline NSAID ${ }^{a}$ & 8 & 9 & 7 & 8 \\
\hline Proton pump inhibitors & 9 & 6 & 9 & 9 \\
\hline $\mathrm{PSA}^{\mathrm{b}}$ & 10 & 10 & 11 & 10 \\
\hline Mammography & 11 & $14-15$ ex aequo & 10 & 14 \\
\hline Cholinesterase inhibitors and memantin & 12 & 11 & 12 & $12-13$ ex aequo \\
\hline Vasodilatator agents & 13 & 13 & 13 & $12-13$ ex aequo \\
\hline DPP4 inhibitor ${ }^{c}$ & 14 & 12 & 14 & 11 \\
\hline Allopurinol & 15 & $14-15$ ex aequo & 15 & 15 \\
\hline
\end{tabular}

\footnotetext{
a Non-steroidal anti-inflammatory

b Prostate specific antigen

c Dipeptidyl peptidase 4 inhibitors
} 
Table 5 Distribution ( $n, \%)$ of factors that influenced the choice of the top five list" from the GrippeNet.fr participants ( $N=691$ )

\begin{tabular}{|c|c|c|}
\hline & $\mathbf{n}$ & $\%$ \\
\hline \multicolumn{3}{|l|}{ Factors influencing the choice of FIVE } \\
\hline \multicolumn{3}{|c|}{ Recommendations of the health authorities (HAS, WHO ...) (m.d. $\left.{ }^{a}=25\right)$} \\
\hline Not at all & 79 & 11.9 \\
\hline Rather not & 109 & 16.4 \\
\hline Rather yes & 336 & 50.4 \\
\hline Absolutely & 142 & 21.3 \\
\hline \multicolumn{3}{|c|}{ Effectiveness of the medical care $(m \cdot d=30)$} \\
\hline Not at all & 43 & 6.5 \\
\hline Rather not & 67 & 10.1 \\
\hline Rather yes & 333 & 50.4 \\
\hline Absolutely & 218 & 33.0 \\
\hline \multicolumn{3}{|l|}{ Tolerance to the medical care $($ m.d. $=25)$} \\
\hline Not at all & 53 & 8.0 \\
\hline Rather not & 128 & 19.2 \\
\hline Rather yes & 306 & 45.9 \\
\hline Absolutely & 179 & 26.9 \\
\hline \multicolumn{3}{|l|}{ Cost of the care procedure $(\mathrm{m} . \mathrm{d} .=28)$} \\
\hline Not at all & 140 & 21.1 \\
\hline Rather not & 182 & 27.4 \\
\hline Rather yes & 216 & 32.6 \\
\hline Absolutely & 125 & 18.9 \\
\hline \multicolumn{3}{|c|}{ Personal history with study care procedure(s) $($ m.d. $=21)$} \\
\hline No, never & 112 & 16.2 \\
\hline Yes, for himself only & 352 & 48.1 \\
\hline Yes, for a close relative only & 68 & 9.8 \\
\hline Yes, for himself and for a close relative & 158 & 22.9 \\
\hline \multicolumn{3}{|c|}{ If yes, carrying out examinations or taking treatments $(m . d .=4)$} \\
\hline No & 12 & 2.2 \\
\hline Not every time & 212 & 38.0 \\
\hline Yes every time & 261 & 46.8 \\
\hline \multicolumn{3}{|c|}{ If yes, have you included these care procedures in your "Top 5"? (m.d.=18) } \\
\hline Yes, 1 only & 185 & 33.2 \\
\hline Yes, 2 & 173 & 31.0 \\
\hline Yes, 3 & 72 & 12.9 \\
\hline Yes, 4 & 21 & 3.8 \\
\hline Yes, the 5 & 28 & 5.0 \\
\hline No, none & 63 & 11.3 \\
\hline
\end{tabular}

${ }^{a}$ m.d. $=$ missing data

these medications by GPs [42]. Since 2009, a re-evaluation of the indications for cough-suppressant therapy has been ongoing in France. In 2010, mucofluidifiers and mucolytics and, in 2011, first-generation anti-histamines and fenspiride were contraindicated for children under two years of age [43]. In 2015, codeine-based cough suppressants were contraindicated for children under 12 years of age [44]. These various waves of delisting may have made patients aware of the dangers associated with certain medications and the lack of efficacy of others. Conversely, anticholinesterase inhibitors and memantine were delisted in 2018 and do not appear in this classification.

Three items were common to the top five list produced by French GPs [19] and that by patients: antibiotic prescriptions, benzodiazepine prescriptions, and statin prescriptions. The first two items are already targeted by the French healthcare system for the reduction of prescriptions because of the high level of prescription in France relative to that of other European countries. Reductions 
in antibiotic and benzodiazepine prescriptions have already been addressed in four $[13-15,17]$ and two $[17$, $18]$ top five lists in general practice, respectively.

Additionally, data from the complementary questionnaire showed that participants had confidence in the recommendations made by various health authorities, although, according to a study, French confidence in the health authorities appeared to have been shaken over the last several years. Indeed, $52 \%$ of 1,000 French individuals put their trust in the public authorities and $33 \%$ in the pharmaceutical industry in 2019 [45].

Finally, cost was considered by only half of the patients. The French public was already aware of the cost of the health system in 2011 in an IPSOS survey, both at the individual and collective level. The survey showed that French people considered "lack of civic-mindedness" as the main explanation for the increase in healthcare spending (abuse/fraud and unnecessary medical acts for 70 and $59 \%$ of the respondents, respectively) [46].

The originality of this study lies in the participation of patients: it is the only top five list created exclusively by patients. The GrippeNet.fr cohort represented several advantages for this project, such as the presence of socio-demographic information, a high interest of participants in public health issues, and the high motivation of participants to participate in new research projects [25]. Additionally, the complementary questionnaire provided information to highlight their choices. Another important strength of this study was that the guides were written with the help of a patient-expert association to ensure that all participants could understand them. The guides created for the purpose of this study could serve as a basis for the creation of adapted shared decision support tools that would be interesting to implement in daily practice. Other studies should be considered to evaluate the impact of such tools on changes in prescribing habits. The three common procedures for the physician and patient lists seem to be a good starting point for effective actions.

This study also had several limitations. First, inherent to volunteer-based cohorts, the GrippeNet.fr population is not representative of the general population. Participants were older, more frequently women, had a higher level of education, and were probably more interested in health issues than the general population [25]. The impact of this potential selection bias is difficult to estimate and is frequently reported [47], although the top five list created by sub-group (age, gender, and level of education) provides reassuring results. This sample, despite its limitations, has the strength for the purpose of the study of being composed of patients who may be in frequent contact with general practice since about one third of them have a chronic disease. Second, in this study, patients were questioned based on the 15 care procedures chosen by the GPs and did not participate in the first pre-selection, which obviously influences the final results. This approach was chosen because patients appear to be unfamiliar with the notion of medical overuse and the concept of over-diagnosis itself is generally misunderstood by patients $[48,49]$. Asking them to provide examples would have been difficult. Third, for some care procedures, the different indications were grouped together in a single guide (e.g. antibiotics) but could lead to different answers in terms of benefit/risk balance.

\section{Conclusion}

This study provides the first top five list in general practice established by patients. It is specific to French healthcare issues. Three care procedures are common between the top five lists of GPs and patients: antibiotic prescriptions, benzodiazepine prescriptions, and statin prescriptions. Efforts can now be focused on these three procedures to reduce their prescription in France. It will be easier to establish actions, such as the development of shared decision support tools, which would be a first step towards initiating dialogue between GPs and patients.

\section{Abbreviations \\ ABIM: American Board of Internal Medicine; CCTIRS: Comité Consultatif sur le Traitement de I'Information en Matière de Recherche; CNIL: Commission Nationale de I'Informatique et des Libertés; GP: General practitioner; HAS: Haute Autorité de Santé.}

\section{Supplementary Information}

The online version contains supplementary material available at https://doi. org/10.1186/s12875-021-01475-z.

Additional file 1.

\section{Acknowledgements}

The authors would like to thank the patients from GrippeNet.fr cohort who took part in the study and and also the Sentinelles GPs. The Authors wish to thank Carla Coelho, Lucie Fournier and Jocelyn Larue who participated in the writing of the guides as well as the completion of the study phase, Thibaud Pitel who created and managed the website and the "Pemphigus Pemphigoïde France" patient association who helped to write the guides. The Authors wish to thank the 17 general practice residents who participated in this study and without whom the study would not have been possible: Marion Abecassi, Henry Baltazard, Sarah Benoit, Bastien Bourrion, Myriam Chemla, Carla Coelho, Blanche D'Anthouard, Olivia De Changy, Florian Dechaine, Jinane El Jabri, Gilles Granero, Caroline Hodara, Jocelyn Larue, Margaux Lebaze, Ludwig Longuet, Pauline Morin, Séverine Steenkiste, Hery Teyssier, Vanessa Vankerk-Hoven.

\section{Authors' contributions}

All authors contributed to the study conception and design. Material preparation, data collection and analysis were performed by $A H, C B, C G, M D$ and MF. $\mathrm{CH}$ created and managed the website. $\mathrm{AH}, \mathrm{CB}, \mathrm{MD}, \mathrm{CG}$ and MF developed the literature summaries. The first draft of the manuscript was written by $A H, C B$ and MD and all authors commented on previous versions of the manuscript. 
All authors read and approved the final manuscript. This work was supervised by MF.

\section{Funding}

This project is funded by the Centre de recherche en Epidémiologie et Santé de Populations (CESP) and the Caisse Nationale d'Assurance Maladie (CNAM) The latter did not participate in the development of the project and has no right to intervene in the conduct of the study.

\section{Availability of data and materials}

All the data of this work are accessible on simple request to the authors.

\section{Declarations}

\section{Ethics approval and consent to participate}

This study was conducted in agreement with French regulations on privacy and data collection and treatment and was approved by the "Comité consultatif sur le traitement de l'information en matière de recherche" (CCTIRS, Advisory committee on information processing for research, authorization 11.565) and the "Commission Nationale de I'Informatique et des Libertés" (CNIL, French Data Protection Authority, authorization DR-2012-024). All methods were performed in accordance with the relevant guidelines and regulations. The patient panel was drawn from the web-based GrippeNet. fr cohort, volunteer-based participatory cohort. The web-based GrippeNet. fr is publicly available. Participant consent is informed and provided through registration on Grippenet.fr website. Study participants could not be identified from the data collected in the study.

\section{Consent for publication}

Not applicable.

\section{Competing interests}

The authors declare that they have no competing interests.

\section{Author details}

${ }^{1}$ Department of Family Medicine, Faculty of Health Sciences Simone Veil, University Versailles-Saint-Quentin-en-Yvelines, Villejuif, Paris, France. ${ }^{2}$ Sorbonne Université, INSERM, Institut Pierre Louis D’Epidémiologie Et de Santé Publique, IPLESP F-75012 Paris, France. ${ }^{3}$ Centre for Research in Epidemiology and Population Health, French National Institute of Health and Medical Research (INSERM U, University Versailles Saint-Quentin-en-Yvelines, University Paris-Sud, 1018), Villejuif, France.

Received: 2 February 2021 Accepted: 25 May 2021

Published online: 26 June 2021

\section{References}

1. Mold JW, Stein HF. The Cascade Effect in the Clinical Care of Patients. N Engl J Med. 1986;314(8):512-4.

2. Morgan DJ, Dhruva SS, Coon ER, Wright SM, Korenstein D. 2018 Update on Medical Overuse. JAMA Intern Med. 2019:179(2):240-6.

3. Morgan DJ, Wright SM, Dhruva S. Update on Medical Overuse. JAMA Intern Med. 2015;175(1):120

4. Jørgensen JT, Andersen JS, Tjønneland A, Andersen ZJ. Determinants of frequent attendance in Danish general practice: a cohort-based crosssectional study. BMC Fam Pract. 2016;17(1):9.

5. Final-Choosing-Wisely-Survey-Report.pdf. [cited 2015 Jun 1]. Available from: http://www.choosingwisely.org/wp-content/uploads/2015/04/ FinalChoosing-Wisely-Survey-Report.pdf. [cited 2018 Mar 15]. Available from: http://www.choosingwisely.org/our-mission/

6. Moynihan R, Nickel B, Hersch J, Beller E, Doust J, Compton S, et al. Public Opinions about Overdiagnosis: A National Community Survey. PLOS ONE. 2015;10(5):e0125165.

7. Moynihan R, Doust J, Henry D. Preventing overdiagnosis: how to stop harming the healthy. BMJ. 2012;344(may28 4):e3502-e3502.
8. Berwick DM, Hackbarth AD. Eliminating Waste in US Health Care. JAMA. 2012;307(14):1513-6.

9. Fisher ES, Bynum JP, Skinner JS. Slowing the Growth of Health Care Costs — Lessons from Regional Variation. N Engl J Med. 2009;360(9):849-52.

10. Antimicrobial-consumption-EU-EEA.pdf. [cited 2020 Nov 10]. Available from: https://www.ecdc.europa.eu/sites/default/files/documents/Antim icrobial-consumption-EU-EEA.pdf

11. Glasziou P, Moynihan R, Richards T, Godlee F. Too much medicine; too little care. BMJ. 2013;347:f4247.

12. Levinson W, Kallewaard M, Bhatia RS, Wolfson D, Shortt S, Kerr EA, et al. "Choosing Wisely": a growing international campaign. BMJ Qual Saf. 2015;24(2):167-74

13. Good Stewardship Working Group. The "top 5 "lists in primary care: meeting the responsibility of professionalism. Arch Intern Med. 2011;171(15):1385-90.

14. Eleven tests and treatments physicians and patients should question in family medicine.. Choosing Wisely Canada. [cited 2018 Jan 30]. Available from: https://choosingwiselycanada.org/family-medicine/

15. Selby, K.,and al.,. "Smarter medicine": 5 interventions à éviter en médecine interne générale ambulatoire. Bull des Médecins Suisses. 2014 [cited 2015 Oct 9]. Available from: http://www.saez.ch/fr/archives/details/smartermedicine-5-interventions-a-eviter-en-mededine-interne-generale-ambul atoire.html

16. General practice tests \& treatments: 5 recommendations from the Royal Australian College of General Practitioners (RACGP). [cited 2016 Feb 24]. Available from: http://www.choosingwisely.org.au/recommendations/ racgp

17. Five Recommendations from the Italian College of General Practice and Primary Care (SIMG) Scheda SIMG english.pdf. Available from: https://www. choosingwiselyitaly.org/PDF/ENGracc/Scheda\%20SIMG\%20english.pdf

18. Recommendations. Choosing Wisely UK. [cited 2019 Jan 15]. Available from: https://www.choosingwisely.co.uk/i-am-a-clinician/recommenda tions/

19. Hazard A, Fournier L, Rossignol L, Pelletier Fleury N, Hervé C, Pitel T, et al. A top 5 list for French general practice. BMC Fam Pract. 2020 09:21(1):161.

20. Grady D, Redberg RF. ADvancing medical professionalism and the choosing wisely campaign —reply. JAMA Intern Med. 2015;175(3):465-465.

21. Hazard A, Pino C, Pelletier-Fleury N, Hanslik T, Saint-Lary O, Blanchon T, et al. «Top five list» française en médecine générale - Protocole de l'étude. exercer. 2017;(134):282-6.

22. Hazard A, Bourrion B, Baltazar H, Fournier L, Francois M. Bénéfices et risques de la prescription d'un traitement homéopathique en prophylaxie antigrippale : exemple de l'influenzinum. Exerc Rev Francoph Médecine Générale. 2018;148(№148):465-71.

23. Bourrion B, Hazard A, Baltazard H, Sebbag P, Fournier L, François M. [Naftidrofuryl in arterial obstructive disease: A systematic revue of the literature]. Rev Med Interne. 2019.

24. Hazard A, Dechaine F, El Jabri J, Fournier L, François M. Bénéfices et risques de la prescription d'allopurinol dans l'hyperuricémie asymptomatique. Exerc Rev Francoph Médecine Générale. 2020;160(N¹60):78-87.

25. Debin M, Turbelin C, Blanchon T, Bonmarin I, Falchi A, HanslikT, et al. Evaluating the Feasibility and Participants' Representativeness of an Online Nationwide Surveillance System for Influenza in France. PLoS ONE. 2013;8(9):e73675.

26. Mathieu P, Gautier A, Raude J, Goronflot T, Launay T, Debin M, et al. Population perception of mandatory childhood vaccination programme before its implementation, France, 2017. Euro Surveill Bull Eur Sur Mal Transm Eur Commun Dis Bull. 2019:24(25).

27. Yazdany J, Schmajuk G, Robbins M, DAIKH D, BEALL A, YELIN E, et al. Choosing Wisely: The American College of Rheumatology's Top 5 List of Things Physicians and Patients Should Question. Arthritis Care Res. 2013:65(3):329-39.

28. Chow SL, Thorne JC, Bell MJ, Ferrari R, Bagheri Z, Boyd T, et al. Choosing Wisely: The Canadian Rheumatology Association's List of 5 Items Physicians and Patients Should Question. J Rheumatol. 2015;42(4):682-9.

29. Langer-Gould AM, Anderson WE, Armstrong MJ, Cohen AB, Eccher MA Iverson DJ, et al. The American Academy of Neurology's top five choosing wisely recommendations. Neurology. 2013;81(11):1004-11. 
30. Nguyen GC, Boland K, Affi W, Bressler B, Jones JL, Weizman AV, et al. Modified Delphi Process for the Development of Choosing Wisely for Inflammatory Bowel Disease: Inflamm Bowel Dis. 2017;23(6):858-65.

31. Ho T, Dukhovny D, Zupancic JAF, Goldmann DA, Horbar JD, Pursley DM. Choosing Wisely in Newborn Medicine: Five Opportunities to Increase Value. Pediatrics. 2015;136(2):e482-489.

32. Ivaldi C. La confiance des Français en leur système de santé. M-Soigner. [cited 2020 Nov 26]. Available from: https://www.m-soigner.com/grandangle/soci\%C3\%A9t\%C3\%A9-et-id\%C3\%A9es/673-la-confiance-desfran\%C3\%A7ais-en-leur-systeme-de-sante.html

33. Sabuncu E, David J, Bernède-Bauduin C, Pépin S, Leroy M, Boëlle P-Y, et al. Significant Reduction of Antibiotic Use in the Community after a Nationwide Campaign in France, 2002-2007. PLOS Med. 2009;6(6):e1000084

34. Trend of antimicrobial consumption by country. European Centre for Disease Prevention and Control. [cited 2020 Jun 30]. Available from: https://www.ecdc.europa.eu/en/antimicrobial-consumption/database/ trend-country

35. Gage SB de, Moride $Y$, Ducruet T, Kurth T, Verdoux $H$, Tournier M, et al. Benzodiazepine use and risk of Alzheimer's disease: case-control study. BMJ. 2014;349. [cited 2020 Jul 6]Available from: https://www.bmj.com/ content/349/bmj.g5205

36. Shash D, Kurth T, Bertrand M, Dufouil C, Barberger-Gateau P, Berr C, et al. Benzodiazepine, psychotropic medication, and dementia: A population-based cohort study. Alzheimers Dement J Alzheimers Assoc 2016;12(5):604-13.

37. Etat des lieux de la consommation des benzodiazépines en France. Agence nationale de sécurité du médicament et des produits de santé; 2017 [cited 2019 Feb 19]. Available from: http://www.pharmacovigilan ce-limoges.fr/sites/default/files/files/Documentation/ANSM_Rapport_ Benzo_2017.pdf

38. Médicaments homéopathiques : une efficacité insuffisante pour être proposés au remboursement. Haute Autorité de Santé. [cited 2020 Jun 30]. Available from: https://www.has-sante.fr/jcms/p_3066934/fr/medic aments-homeopathiques-une-efficacite-insuffisante-pour-etre-propo ses-au-remboursement

39. La EP. vérité sur le cholestérol. Paris: Le Cherche Midi; 2013.

40. Bezin J, Francis F, Nguyen NV, Robinson P, Blin P, Fourrier-Réglat A, et al. Impact of a public media event on the use of statins in the French population. Arch Cardiovasc Dis. 2017;110(2):91-8.
41. Descamps O, Claeys M, Lancellotti P, Pasquet A, Buysschaert M, Kacenelenbogen $\mathrm{R}$, et al. Réaction des sociétés scientifiques et des associations de patients face à une émission d'ARTE "Cholestérol, le grand bluff!":6.

42. Devaux M, Grandfils N, Sermet C. Déremboursement des mucolytiques et des expectorants : quel impact sur la prescription des généralistes? 2007;6.

43. Nouvelles modalités de prise en charge de la toux chez le nourrisson (enfant de moins de 2 ans) - Point d'information - ANSM : Agence nationale de sécurité du médicament et des produits de santé. [cited 2020 Jul 6]. Available from: https://ansm.sante.fr/S-informer/Points-d-informationPoints-d-information/Nouvelles-modalites-de-prise-en-charge-de-latoux-chez-le-nourrisson-enfant-de-moins-de-2-ans-Point-d-information

44. ANSM. Nouvelles restrictions d'utilisation de la codéine dans le traitement de la toux - Lettre aux professionnels de santé. http://ansm.sante. fr. 2015. Available from: http://ansm.sante.fr/S-informer/Informations-desecurite-Lettres-aux-professionnels-de-sante/Nouvelles-restrictions-dutilisation-de-la-codeine-dans-le-traitement-de-la-toux-Lettre-aux-profe ssionnels-de-sante

45. Les "Fake news" dans le domaine de la santé - Décembre 2019 - Viavoice [Internet]. [cited $2020 \mathrm{Jul}$ 16]. Available from: http://www.institut-viavoice com/fake-news-sante-decembre2019/

46. Les Français et le système de santé. Ipsos. [cited 2020 Jul 16]. Available from: https://www.ipsos.com/fr-fr/les-francais-et-le-systeme-de-sante

47. Enzenbach C, Wicklein B, Wirkner K, Loeffler M. Evaluating selection bias in a population-based cohort study with low baseline participation: the LIFE-Adult-Study. BMC Med Res Methodol. 2019;19(1):135.

48. Moynihan R, Nickel B, Hersch J, Beller E, Doust J, Compton S, et al. Public Opinions about Overdiagnosis: A National Community Survey. PLoS ONE. 2015 May 20 [cited 2017 Jan 26];10(5). Available from: http://www.ncbi. nlm.nih.gov/pmc/articles/PMC4439083/

49. Moynihan R, Nickel B, Hersch J, Doust J, Barratt A, Beller E, et al. What do you think overdiagnosis means? A qualitative analysis of responses from a national community survey of Australians. BMJ Open. 2015;5(5):e007436.

\section{Publisher's Note}

Springer Nature remains neutral with regard to jurisdictional claims in published maps and institutional affiliations.
Ready to submit your research? Choose BMC and benefit from:

- fast, convenient online submission

- thorough peer review by experienced researchers in your field

- rapid publication on acceptance

- support for research data, including large and complex data types

- gold Open Access which fosters wider collaboration and increased citations

- maximum visibility for your research: over $100 \mathrm{M}$ website views per year

At BMC, research is always in progress.

Learn more biomedcentral.com/submissions 